\title{
Makerspaces in Higher Education : the UR-Maker experience at the University of La Rioja
}

\author{
Pernia-Espinoza, Alpha \\ UNIVERSITAT POLITECNICA DE VALENCIA \\ 2017
}

Pernia-Espinoza , A, Sodupe-Ortega , E , Pecina-Marqueta , S , Martinez-Banares , S , Sanz Garcia , A \& Blanco-Fernandez , J 2017 , Makerspaces in Higher Education : the UR-Maker experience at the University of La Rioja . in J Domenech i Soria , M C Vincent Vela , E de la Poza \& D Blazquez (eds) , HEAd'17 : proceedings of the 3rd international conference on higher education advances. UNIVERSITAT POLITECNICA DE VALENCIA, Valencia , pp. 758-765, HEAd'17. International conference on higher education advances , Valencia , Spain , 21/06/2017 . https://doi.org/10.4995/HEAd17.2017.5400

http://hdl.handle.net/10138/228152

https://doi.org/10.4995/HEAd17.2017.5400

cc_by_nc_nd

publishedVersion

Downloaded from Helda, University of Helsinki institutional repository.

This is an electronic reprint of the original article.

This reprint may differ from the original in pagination and typographic detail.

Please cite the original version. 


\title{
Makerspaces in Higher Education: the UR-Maker experience at the University of La Rioja
}

\author{
Pernía-Espinoza, Alpha ${ }^{a}$; Sodupe-Ortega, Enrique ${ }^{a}$; Peciña-Marqueta, Sergio ${ }^{\text {; }}$ \\ Martínez-Bañares, Sergio ${ }^{\text {; }}$ Sanz-García, Andrés ${ }^{b}$ and Blanco-Fernández, Julio ${ }^{a}$ \\ ${ }^{a}$ Department of Mechanical Engineering, University of La Rioja, Spain. \\ ${ }^{b}$ Faculty of Pharmacy, Centre of Drug Research (CDR), University of Helsinki, Finland.
}

\begin{abstract}
Nowadays, in addition to the expected technical knowledge, labor markets demand engineers with personal, interpersonal and system building skills, according to the CDIO (Conceive-Design-Implement-Operate) syllabus. But the current higher education systems are mostly teaching theoretical concepts rather than practical or applied cases. Makerspaces could become a bridge between universities and industry, particularly in STEM (Science, Technology, Engineering, and Math) careers. Makerspaces, also known as hackerspaces, hack labs, and fab labs, are open-access spaces where tools, machines and knowledge are shared with the purpose of implementing an idea. This communication evaluates the current status of the makerspaces at the world's top 10 universities in engineering and three of the most wellknown Spanish ones, as well as the new campus makerspace created at the University of La Rioja. All the information was collected from universities' websites. Most of these reviewed universities have created outstanding makerspaces generally for the entire academic community. The Spanish 'Maker UPV' has been exceptionally successful promoting activities and projects in spite of the lack of resources reported. Lastly, the implementation of a new makerspace at the University of La Rioja (UR-Maker) is described with information about its organization, funding sources and activities already performed. This experience can represent an attractive guide for the academic community as other universities can explore the creation of new makerspaces on their own campus.
\end{abstract}

Keywords: Makerspace; higher education; hands-on; PBL; engineering degrees. 


\section{Introduction}

According to the recognized conceive-design-implement-operate (CDIO) syllabus (Crawley, 2002), graduating students in engineering must achieve personal and professional attributes apart from technical knowledge. These competences will facilitate students to enter the working world and evolve in their future working lives. The current educational system is, however, primarily built on theoretical concepts rather than on real cases (Barrett et al., 2015). In this sense, project based learning (PBL) offers a way to promote this students' active learning approach by using realistic and applied projects that introduce practical work into the curriculum (Gary, 2015). Nevertheless, the definition of the appropriate learning environment is not an easy task, hindering the inclusion of significant PBL experiences into engineering education (Grahm, 2010). A makerspace could become this suitable learning environment needed. Makerspaces are physical open-access spaces where a community shares tools, machines, and knowledge to give shape and life to an idea. Design, modify, build, test or repair are usual activities performed in the makerspaces. As a result, makerspaces could become a strategic element towards the inclusion of autonomous and social learning, developing the creativity competence through divergent thinking and innovation (Liu and Schönwetter, 2004; Thompson and Lordan, 1999). The New Media Consortium (NMC) Horizon Report: 2015 (Johnson et al., 2015) highlighted the importance of makerspaces within the higher education context and forecast deadline to achieve widespread adoption in two or three years. Neil Gershenfield was one of the pioneers on this kind of learning environment creating the first FabLab at the Massachusset Institute of Technology (MIT) in 2001 (Walter-Herrmann and Büching, 2013). The idea behind the makerspaces has grown one on one with the Do It Yourself (DIY) movement, an open-source philosophy that intends to democratize the technology becoming accessible to everyone (Hatch, 2013). Aware of its importance, some of the most prestigious US universities (according to the QS World University Ranking (Rankings, 2016)) have joint efforts under the Higher Education Makerspaces Initiative (HEMI) (HEMI, 2017) to promote, develop and share the best practices in academic makerspaces. Contrary to the common thinking, and the data extracted from makerspaces at the US universities, a reduced budget is enough to start a makerspace in a university campus. Through their experiences, the authors demonstrate that a new makerspace requires minimum financial and human effort. This could be a useful guideline for other universities to explore the creation of new makerspaces on their own campus.

This communication evaluates makerspaces created by the ten top-rated worldwide engineering universities and three makerspaces at well-known Spanish universities. Moreover, authors detail their own experiences during the creation of a new makerspace at the Universidad de La Rioja. 


\section{Makerspaces in higher education. Current status}

The methodology applied to search and organize the information about university makerspaces followed the work of (Barrett et al., 2015), in which the top 100 universities in the United States were evaluated. Another valuable reference for the methodology presented herein comes from a recent work that reviewed a total of 43 Australian universities (Wong and Partridge, 2016). Importantly, our communication makes no distinction between the different terms associated to a makerspace, such as hackerspace, hack lab, or fab lab. It is assumed that all of them represent a place for informal, hands-on learning. According to the QS World University Ranking (Rankings, 2016) in the "Engineering - Mechanical, Aeronautical \& Manufacturing" subject, the world's top 10 universities are (Table 1): $\mathrm{N}^{\circ} 1$. MIT, $\mathrm{N}^{\circ} 2$. Stanford University (StfU), No3. University of Cambridge (UCm), $\mathrm{N}^{\circ} 4$. University of California-Berkeley (UCB), $\mathrm{N}^{\circ} 5$. Imperial College London (ICL), $\mathrm{N}^{\circ} 6$. University of Michigan (UMch), $\mathrm{N}^{\circ} 7$ Harvard University (HvdU), $\mathrm{N}^{\circ} 8$. National University of Singapur (NUS), $\mathrm{N}^{\circ} 9$. University of Oxford (UOxf) and $\mathrm{N}^{\circ} 10$. Georgia Institute of Technology (GIT). Concerning the Spanish makerspaces, the top 3 Spanish engineering universities were selected for this study: $\mathrm{N}^{\circ} 82$. Universidad Politécnica de Cataluña (UPC), Nº130. Universidad Politécnica de Madrid (UPM) and $\mathrm{N}^{\circ} 160$. Universidad Politécnica de Valencia (UPV).

\begin{tabular}{|c|c|c|c|}
\hline Ranking & & $\begin{array}{l}\text { Makerspace } \\
\text { Name. }\end{array}$ & Website \\
\hline $\mathrm{N}^{\circ} 1$ & MIT & 'MakerWorks' & http://makerworks.mit.edu/ \\
\hline $\mathrm{N}^{\circ} 2$ & StfU & $\begin{array}{l}\text { 'Stanford Production } \\
\text { Realization Lab' }\end{array}$ & https://productrealization.stanford.edu/even \\
\hline$N^{\circ} 3$ & $\mathrm{UCm}$ & $\begin{array}{l}\text { 'Dyson Centre } \\
\text { for Engineering Design' }\end{array}$ & http://www.dysoncentre.eng.cam.ac.uk/ \\
\hline $\mathrm{N}^{\circ} 4$ & UCB & 'SuperNode' & https://supernode.berkeley.edu/ \\
\hline $\mathrm{N}^{\circ} 5$ & ICL & $\begin{array}{l}\text { 'Imperial College Advanced } \\
\text { Hackspace' }\end{array}$ & $\begin{array}{l}\text { http://www.imperial.ac.uk/advanced- } \\
\text { hackspace }\end{array}$ \\
\hline $\mathrm{N}^{\circ} 6$ & UMch & $\begin{array}{l}\text { 'Wilson Student Team } \\
\text { Project Center' }\end{array}$ & http://teamprojects.engin.umich.edu/ \\
\hline $\mathrm{N}^{\circ} 7$ & HvdU & 'i-lab’ & https://i-lab.harvard.edu/ \\
\hline $\mathrm{N}^{\circ} 8$ & NUS & 'Makerspace/FabLab’ & http://makerspace.sp.edu.sg/f \\
\hline $\mathrm{N}^{\circ} 9$ & UOxf & 'Radcliffe Science Library' & $\begin{array}{l}\text { http://www.bodleian.ox.ac.uk/science/use/3 } \\
\text { d-printing }\end{array}$ \\
\hline$N^{\circ} 10$ & GIT & 'Invention Studio' & http://inventionstudio.gatech.edu/ \\
\hline$N^{\circ} 82$ & UPC & 'FabLab Terrassa' & $\begin{array}{l}\text { https://www.eet.upc.edu/curs- } \\
\text { actual/activitats-i-beques/fablab- } \\
\text { terrassa?set language }=\text { es }\end{array}$ \\
\hline $\mathrm{N}^{\circ} 130$ & UPM & 'FabLab UPM' & $\begin{array}{l}\text { http://colaboratorio.eu/Public html/FabLab } \\
\text { UPM/ }\end{array}$ \\
\hline $\mathrm{N}^{\circ} 160$ & UPV & 'Makers UPV' & https://makersupv.com/ \\
\hline
\end{tabular}

Table 1. Websites of the makerspaces at the top 10 universities worldwide and the makerspaces at the top 3 Spanish universities. 
The compiled information about the accessibility of every makerspace, payments, staff involved and equipment available is listed in Table 2.

\begin{tabular}{|c|c|c|c|c|c|c|c|c|c|c|c|c|c|}
\hline & 兒 & 宽 & 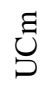 & 己ِ & 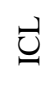 & $\sum_{S}^{\frac{J}{0}}$ & 胥 & $\stackrel{\Omega}{\text { Z }}$ & ర్ & $\mathrm{E}$ & S & $\sum_{S}$ & s \\
\hline \multicolumn{14}{|l|}{ ACCESS } \\
\hline $\begin{array}{l}\text { Engineering students } \\
\text { only }\end{array}$ & $X$ & & $X$ & & & & & & & & & & \\
\hline $\begin{array}{l}\text { All University } \\
\text { community }\end{array}$ & & $\mathrm{X}$ & & $X$ & $\mathrm{X}$ & $\mathrm{X}$ & $X$ & $\mathrm{X}$ & $X$ & $\mathrm{X}$ & $X$ & $X$ & $\mathrm{X}$ \\
\hline External access & & & & & & & & & & & $X$ & $X$ & \\
\hline \multicolumn{14}{|l|}{ PAYMENT } \\
\hline Free & $X$ & & $\mathrm{X}$ & $\mathrm{X}$ & $\mathrm{X}$ & $\mathrm{X}$ & $\mathrm{X}$ & $\mathrm{X}$ & $X$ & $X$ & & & $\mathrm{X}$ \\
\hline Pay for membership & & $\mathrm{X}$ & & & & & & & & & $\mathrm{X}$ & $\mathrm{X}$ & \\
\hline Pay/bring material & $X$ & $\mathrm{X}$ & $\mathrm{X}$ & $\mathrm{X}$ & $\mathrm{X}$ & $\mathrm{X}$ & $X$ & $X$ & $\mathrm{X}$ & $\mathrm{X}$ & $X$ & $\mathrm{X}$ & $\mathrm{X}$ \\
\hline \multicolumn{14}{|l|}{ STAFF } \\
\hline Student Run & $\mathrm{X}$ & & & $X$ & & & & & & $X$ & & & $\mathrm{X}$ \\
\hline Faculty Run & & $\mathrm{X}$ & $\mathrm{X}$ & & $\mathrm{X}$ & $\mathrm{X}$ & $\mathrm{X}$ & $\mathrm{X}$ & & & & & \\
\hline Specific Staff & & $\mathrm{X}$ & $\mathrm{X}$ & & $\mathrm{X}$ & $\mathrm{X}$ & $\mathrm{X}$ & $\mathrm{X}$ & $X$ & & $\mathrm{X}$ & $\mathrm{X}$ & \\
\hline \multicolumn{14}{|l|}{ EQUIPMENT } \\
\hline 3D printer & $X$ & $\mathrm{X}$ & $\mathrm{X}$ & $\mathrm{X}$ & $\mathrm{X}$ & $\mathrm{X}$ & $X$ & $\mathrm{X}$ & $\mathrm{X}$ & $\mathrm{X}$ & $\mathrm{X}$ & $\mathrm{X}$ & $\mathrm{X}$ \\
\hline Laser cutter & $\mathrm{X}$ & $X$ & $X$ & & $X$ & $X$ & & & & $X$ & $\mathrm{X}$ & $\mathrm{X}$ & \\
\hline 3D scanner & & $X$ & & & $X$ & $X$ & & & $X$ & $X$ & $\mathrm{X}$ & $X$ & \\
\hline Wood shop & $X$ & $X$ & $X$ & & $X$ & $X$ & & & & $X$ & $\mathrm{X}$ & $X$ & \\
\hline Metal shop & $\mathrm{X}$ & $X$ & $X$ & & $X$ & $X$ & & & & $X$ & $\mathrm{X}$ & $X$ & \\
\hline Electronics & $X$ & $X$ & $X$ & $X$ & $X$ & $X$ & $\mathrm{X}$ & $\mathrm{X}$ & & $X$ & $\mathrm{X}$ & $X$ & $\mathrm{X}$ \\
\hline Computer & $X$ & $X$ & $X$ & $X$ & $X$ & $X$ & $X$ & $X$ & $X$ & $X$ & $X$ & $X$ & $\mathrm{X}$ \\
\hline Photography booth & $\mathrm{X}$ & $\mathrm{X}$ & & & $\mathrm{X}$ & & $\mathrm{X}$ & $\mathrm{X}$ & & & $\mathrm{X}$ & $\mathrm{X}$ & \\
\hline
\end{tabular}

Table 2. Makerspaces information regarding accessibility, payments, staff and equipment.

\section{Results and Discussion}

This communication collected public information about makerspaces from the website of the 13 universities selected. We assume that this may generate some misinterpretation or missing information concerning the current status of the makerspaces evaluated. Future studies in this aspect should explore deeper by carrying out some interviews or visits to verify the published information. In concordance with (Barrett et al., 2015) and (Wong and Partridge, 2016) observations, we encountered a wide variety of makerspaces at the 13 schools studied. These US universities have indeed very well equipped makerspaces within their campuses, similar to the quality of their laboratories and technical workshops. For instance, MIT, StfU, UCm, ICL, UMch, GIT, UPC and UPM count on outstanding and full-equipped official makerspaces, some only for engineering students. Most of these 
makerspaces studied offer open-access for all the university community, except MIT and University of Cambridge that only allow engineering students. Other cases are StfU, UPC and UPM makerspaces, which require an initial payment to become an official user. Some makerspaces such as UCB are created mainly oriented to work on 3D printing, robotic and electronic devices. HrdU have a whole building devoted to entrepreneurs on any field with access to $3 \mathrm{D}$ printing, electronics and rubber molding. The UOxf and NUS makerspaces are located inside the library and mainly oriented to experiment with 3D printing and electronics. A common practice is to request users to bring or pay for the material to be used. Regarding organization, both faculty and technical (dedicated) staff are running the makerspaces. The websites of the MIT, UCB, GIT and UPV student-run-makerspaces are well-organized and very active in personal projects and national and international competitions. In other cases such as the Supernode (UCB) and 'Maker UPV' (UPV), students' initiative was an essential factor for their creation, and they are still mostly run by these groups of students. All these cases of makerspaces share something in common, that is, the first resources incorporated are always the 3D printers, together with some computers. These observations are in agreement with those reported by (Barrett et al., 2015) and (Wong and Partridge, 2016).

Regarding the Spanish universities studied, it is worth highlighting that 'Makers UPV' has neither headquarters nor fixed material resources. However, they are one of the most active campus makerspaces in Spain. 'Makers UPV' is a free-access makerspace, run solely by students with remarkable national and international recognition. Recently, they also won some prestigious competitions such as the 'Hyperloop Space X', 2016 edition (www.spacex.com/hyperloop). They also promote enlightening and educational activities about technology for children. This situation demonstrates that it is not indispensable to count on a sizable budget to implement an efficient campus makerspace. Lastly, authors' experience on building up the University of La Rioja makerspace (UR-maker) is reported in the following sections as an example of a makerspace with significant presence of students' initiative.

\section{The UR-Maker Experience}

The University of La Rioja (UR) (www.unirioja.es) is a relatively small university with around 7k students and 9 STEM (Science, Technology, Engineering, and Math) degrees. UR-Maker project emerged thanks to students' initiative and faculty staff involvement. After understanding the importance of a makerspace in higher education, an enthusiastic UR governing body joined the project and the UR-Maker was officially inaugurated at the end of 2016 (October $19^{\text {th }}$ ). The UR-Maker is run by students and faculty staff and has well-equipped, free-access makerspace for the entire university community. 


\subsection{Space layout}

One of the most complicated steps when creating a makerspace is to find a physical space inside university buildings. Luckily, an underused metrology laboratory was available. After some minor changes we adapted this space as a makerspace, distributing its $88 \mathrm{~m}^{2}$ in 8 different areas: 3D printing, electronics, hand-tools, machining, 3D scanning, assembly, design and quality control zones. The laboratory has natural light, one entrance, and the compulsory emergency exit. The location into the campus is extraordinary being near a room equipped with computers for design and simulation activities, and the main manufacturing workshop of the engineering school.

\subsection{Kick-Starter of the UR-Maker and economic sustainability}

The total amount of investment at this moment is $9 \mathrm{k} €$. The university provided the starting funding of $6 \mathrm{k} €$ for buying new 3D desktop printers with friendly interface and auto-leveling system, which are essential for facilitate the use of the machine among the novel users. Other components for DIY activities included: common tools (hammers, pliers, screwdrivers, etc.); small power tools (rotatory tools, small drill-press, drill, fretsaw, jigsaw, etc.); measurement tools (handheld multimeter, electronic calipers, etc.); a basic photo set (to document the projects) and basic mechanical and electronic items. Additionally, several DIY desktop machines (three RepRap 3D printers, a mini CNC-PCBmill and a mini 3D scanner) were purchased thanks to three consecutive teaching innovation projects (APIDUR 2013, 2014 and 2015). Furthermore, understanding the relevance of the project, all departments transferred several items to the makerspace (electronic equipment, lockers, etc.). Because of the proximity and open access to the campus manufacturing workshop we have not include heavy machine tools in the URMaker. The size of the budget shows that it is not indispensable lots of money.

The current funding mechanisms of the UR-Maker include the university's internal budget, projects with local companies and various collaboration agreements with other entities such as www.fffworld.com/en/, www.bq.com/es/mundo-3d, www.jae.es/, and www.aprendiendoarduino.com. Some donations from private organizations (http://www.leroymerlin.es/) also increased the budget for 2017. Finally, the users have to bring or pay for the materials used as in most of the other makerspaces studied.

\subsection{Website and social networks}

The recruitment of users, publication of news and courses is always broadcasted on the website: http://www.unirioja.es/urmaker/, or by social media networks such as Facebook: https://www.facebook.com/areaURmaker/ and Twitter: https://twitter.com/area urmaker. 


\subsection{Activities at the UR-Maker}

UR-Maker has become a meeting point for knowledge and experiences exchange, fostering in this way a maker community with several academic and personal projects hosted. Free basic and advanced training courses (3D design \& printing, Arduino, etc.), social projects (3D printed toys for Christmas) and some local competitions have been carried out. Several open door days for people outside the university community were also organized to spread the maker movement. Concerning research groups and departments, the Maker-UR has been a tool for supporting some R\&D and academic activities. For instance, 'Unirioja Racing Team' received supported for its preparation for the international competition Motostudent 2016. Shortly, we expect to increase the number of collaborations and agreements between the university and some companies.

\subsection{Current limitation the UR-Maker}

Several limitations were detected during the implementation of the UR-Maker. As a new entity in the UR, none staff has been permanently designated for organizing the makerspace, task mainly relying on students and faculty staff. Therefore, it is hard to generate long-term schedules, especially without an annual budget. Medium and long-term plans depends on personal and professional circumstances. Regarding accessibility and security, an automatic access system should be installed to allow registered and trained user to work in the UR-Maker. Authors are still working on these problems to enhance the services provided and increase the number of activities organized.

\section{Conclusions}

Makerspaces are community centers that provide a creative environment for active learning where hands-on and interactive elements are essential components. Makerspaces are also growing in the university campuses, particularly around the STEM careers, for being a bridge between academy and labor market. Herein, we evaluated the makerspaces of the top 10 engineering universities in the world, and three of the most well-known in Spain. Aware of their importance, most of these universities count on outstanding makerspaces, with 3D printers as the most common equipment for students in engineering degrees, and some of them are open to the entire university community. Interestingly, most of the students-runmakerspaces were originated by their own initiative. Nevertheless, active faculty members or staff is commonly the managers of most makerspaces. An exceptional case was found in 'Maker UPV' with very interesting activities and outstanding achievements in spite of their lack of material resources. We also described authors' own experience implementing a campus makerspace (http://www.unirioja.es/urmaker/). Surprisingly, we did not find indispensable a sizable budget to start a makerspace in a university campus. Next steps will 
include formal interviews for the assessment of the impact and relevance of the described makerspaces.

\section{Acknowledgements}

The authors would like to acknowledge the financial support received from the University of La Rioja through the programs 'Proyectos de Innovación Docente 2016/2017', and the FPI-UR fellowship (E. S). The authors also want to express their gratitude to the Instituto de Estudios Riojanos (IER). One of the authors, A.S.G., would also like to acknowledge the financial support from the Academy of Finland No. 273689. Finally, we would like to thank the students and university staff involved in the UR-Maker project.

\section{References}

Barrett, T., Pizzico, M., Levy, B., Nagel, R., Linsey, J., Grau, K., Forest, C., Newstetter, W., 2015. A Review of University Maker Spaces, 122nd American Society for Engineering Education Annual Conference \& Exposition, Seattle, Washington. USA.

Crawley, E., 2002. Creating the CDIO syllabus, a universal template for engineering education, 32nd ASEE/IEEE Frontiers in Education Conference. IEEE, Boston, Massachusetts. USA, pp. 1-6.

Grahm, R., 2010. UK Approaches to Engineering Project-Based Learning, Report form the Gordon-MIT Engineering Leadership Program at MIT. Massachusetts Institute of Technology: MIT, Massachuset, USA.

Hatch, M., 2013. The Maker Movement Manifesto: Rules for Innovation in the New World of Crafters, Hackers, and Tinkerers, 1st ed. McGraw-Hill Education.

HEMI, 2017. Higher Education Makerspaces Initiative - HEMI. Developing and sharing best practices for academic makerspaces. http://hemi.mit.edu/.

Johnson, L., S., A., Estrada, V., Freeman, A., 2015. NMC horizon report: 2015 higher education edition. The New Media Consortium, Austin, TX. USA.

Liu, Z., Schönwetter, D., 2004. Teaching Creativity in Engineering. International Journal of Engineering Education 20, 801-808.

Rankings, Q.W.U., 2016. QS World University Rankings by Subject 2016 - Engineering Mechanical, Aeronautical \& Manufacturing.

Thompson, G., Lordan, M., 1999. A review of creativity principles applied to engineering design. Proceedings of the Institution of Mechanical Engineers, PartE: Journal of Process Mechanical Engineering 213, 17-31.

Walter-Herrmann, J., Büching, C., 2013. FabLab of Machines, Makers and Inventors. Majuskel medienproduktion Gmbh., Hannover, Germany.

Wong, A., Partridge, H., 2016. Making as Learning: Makerspaces in Universities. Australian Academic \& Research Libraries 47, 143-159. 